UDK: $342.727: 168.2$

Pregledni članak

Primljeno: 27. 9. 2020.

Prihvaćeno za štampu: 23. 11. 2020.

Dr. sc. Nevzet Veladžić, redovni profesor

Univerzitet u Bihaću

E-mail:nevzet2005@yahoo.com

Mr. sc. Anita Ramulić-Mujkić, as.

Univerzitet u Bihaću

Islamski pedagoški fakultet

E-mail:anita_ramuli@yahoo.com

\title{
SLOBODA IZRAŽAVANJA - ANALIZA PRESUDA EVROPSKOG SUDA ZA LJUDSKA PRAVA (ČLAN 10)
}

\section{Sažetak}

Sloboda irražavanja je jedan od najvažnijih kategorija u domenu ljudskih prava i često je predmet sporenja u pravnim krugovima posebno u pogledu ograničenja slobode iquǎ̃avanja. Navedeno pravo regulisano je članom 10. Evropske konvencije za zaštitu ljudskih prava i osnounih sloboda s posebnim aspektom na ograničnje iste. Stoga se kao najvažniji kriterij postavlja činjenica da se sloboda izražavanja kao pravo ispoljava sve do momenta dok, „ne dira/ ugrožava" u pravo neke tré́e osobe. U radu su predstavljene osnovne odrednice slobode izražavanja s osvrtom na ograničenje slobode izražavanja te analizu presuda Evropskog suda za ljudska prava (član 10) u pogledu ograničenja iste.

Ključne riječi: sloboda iðražavanja, Evropska konvencija za zaštitu ljudskih prava i sloboda, ograničenje slobode irražavanja

\section{Uvodna kontekstualizacija problema}

Sloboda izražavanja mišljenja, uvjerenja i ideja jedna je od osnovnih ljudskih prava i jedan od bitnih zahtjeva demokratskog društva. U nastavku izlaganja prezentirat će se osnovne odrednice slobode 
izražavanja, ograničenja iste u skladu s članom 10, stav 2. Evropske konvencije za zaštitu ljudskih prava i temeljnih sloboda te analiza presuda Evropskog suda za zaštitu ljudskih prava i temeljnih sloboda u domenu primjene člana 10, Evropske konvencije.

\section{Sloboda izražavanja}

Član 19. Opće deklaracije o ljudskim pravima (ODLJP) iz 1948. godine kaže: „Svako ima pravo na slobodu mišljenja i izražavanja“. Navedeno pravo podrazumijeva slobodu izražavanja mišljenja bez vanjskih pritisaka te slobodu traženja, primanja i širenja informacija i ideja putem bilo kojeg sredstva javnog informisanja bez obzira na granice. ${ }^{1}$

Poznato je da su Andrej Aleksandrovič Ždanov, sovjetski političar simbol boljševičke indoktrinacije i Paul Jozef Gebels, koji je isto značio u fašizmu, bili odlučni protivnici slobode izražavanja. Sve opresivne snage, od nedemokratske države do različitih ekonomskih, finansijskih i političkih monopolskih organizacija, oštro se protive ljudskom pravu izražavanja, jer ono demistificira privatne, partikularne i druge egoistične interese, i time im smanjuje šanse za uspjeh. ${ }^{2}$

Sloboda izražavanja predstavlja pravo koje je zaštićeno Konvencijom, međutim sloboda izražavalja predstavlja i komponentu drugih prava koja su zaštićena Konvencijom, kao što je sloboda okupljanja. Međutim sloboda izražavanja može da bude u animozitetu s drugim pravima koja su zaštićena po Konvenciji kao što je pravo na pravično suđenje, na poštovanje privatnog života, na slobodu savjesti i vjeroispovijesti. Kada dođe do takvih konfliktnih situacija, Sud uspostavlja ravnotežu jednog prava u odnosu na drugo.

\subsection{Zaštita slobode izražavanja prema Evropskoj konvenciji (član 10)}

Član 10. Konvencije propisuje slobodu izražavanja što uključuje slobodu mišljenja, slobodu primanja, prenošenja informacija i ideja,

\footnotetext{
${ }^{1}$ Monica Macovei, Vodič za primjenu Člana 10, Europske konvencije o ljudskim pravima (Priručnik iz oblasti ljudskih prava br.2), Savjet Europe, Strasbourg Cedex, 2008. godine, str. 6.

${ }^{2}$ Ćazim Sadiković, Europsko pravo, Magistrat, Sarajevo, 2001. godine, str. 105.
} 
bez miješanja javne vlasti i bez obzira na granice. Ograničenje slobode izražavanja predviđa se pod uslovima predviđenim u stavu 2, što podrazumijeva ograničenje ili sankciju predviđenu zakonom i koje su neophodne u demokratskom društvu u interesu nacionalne sigurnosti, teritorijalnog integriteta ili javne sigurnosti, sprečavanje nereda ili zločina, zaštite zdravlja i morala, ugleda ili prava drugih, sprečavanja širenja povjerljivih informacija ili $u$ interesu očuvanja autoriteta $i$ nepristranosti sudstva. Pravo na slobodu izražavanja je izuzetno važno u društvu jer je ono, kako smo vidjeli, preduvjet demokratskog društva. Međutim pravo na slobodu izražavanja podrazumijeva i odgovornosti pošto može biti u sukobu s drugim pravima pojedinaca, naprimjer, pravo na privatnost. Stoga se Evropski sud (primjenjući član 10) često morao baviti delikatnim pitanjima koja se odnose na uspostavu ravnoteže između prava na slobodu izražavanja i drugih prava zagarantovanih konvencijom. ${ }^{3}$

Važno je konstatovati da je sloboda posjedovanja mišljenja osnovna pretpostavka za druge slobode garantovane članom 10, nadalje ova sloboda uživa gotovo apsolutnu zaštitu u smislu da se moguće restrikcije izložene u stavu 2 ne primjenjuju. Kako je naveo i Komitet ministara Savjeta Evrope, "sva ograničenja ovog prava smatraju se nespojivima sa prirodom demokratskog društva". Države ne smiju pokušavati da indoktriniraju svoje građane, niti im treba omogućiti da prave bilo kakvu razliku između pojedinaca na osnovu posjedovanja nekog mišljenja. U okviru slobode posjedovanja mišljenja, pojedinci su, također, zaštićeni od mogućih negativnih posljedica u slučajevima gdje se posebna mišljenja njima pripisuju zbog prethodnih javnih izražavanja mišljenja. Sloboda posjedovanja mišljenja obuhvata i negativnu slobodu da lice ne bude primorano da izrazi svoje sopstveno mišljenje.

\subsection{Sadržaj prava na slobodu izražavanja (sudska praksa)}

Termin ,sloboda izražavanja“" nije ograničen na član 10. On obuhvata sve oblike izražavanja, kako usmene, tako i putem štampanih i elektronskih medija. Navedeni član obuhvata sve informacije, ne samo

${ }^{3}$ Harland Christoper, Komentar Europske konvencije o ljudskim pravima: prema praksi u BiH i Strazburgu, Sarajevo, 2003. godine, str. 243. 
političke. Pod taj član potpada bilo koja informacija koja se može pojaviti u javnosti bez obzira na njen sadržaj.

\section{U predmetu Markt Intern Verlang GmbH protiv Njemačke (presuda} Evropskog suda od 20.novembra 1989. godine, Serija A, broj 165) argument Njemačke pred Sudom bio je da informacije sadržane $u$ jednom časopisu o trgovini koje se tiču komercijalnih aktivnosti ne trebaju biti zaštićene članom 10 ili barem treba da budu na samim marginama zaštite koju propisuje taj član. Sud je odlučio da se član 10 ne primjenjuje isključivo na određene vrste informacija ili ideja, odnosno, oblika izražavanja. U predmetu Autronic protiv Švicarske Sud je odlučio da se član 10 primjenjuju i na satelitske signale koji se koriste kao tehničko sredstvo za prenos informacija. ${ }^{4}$

Mnogi predmeti koje je razmatrao Evropski sud u skladu s članom 10 tiču se slobode štampe. Jedan od najpoznatijih predmeta u ovoj oblasti je Sunday Times protiv Ujedinjenog Kraljevstva (presuda Evropskog suda od 26. aprila 1979. godine, Serija A br. 30). Presuda Sunday Timesa protiv Ujedinjenog Kraljevstva (br. 1) od 26. aprila 1979. Serija A br. 30, jedan je od vodećih predmeta na kojima je Sud temeljio svoje zaključke u predmetu Observer i Guardian. U tom predmetu su podnosioci željeli objaviti tekst o načinu na koji je jedna firma testirala medikament (Thalidomide) prije nego što ga je plasirala na tržište. Medikament je proizveo štetne efekte i žrtve su pokrenule sudski postupak. Navedena farmaceutska kompanija uspjela je dobiti zabranu objavljivanja datog teksta, na osnovu tvrdnje da bi tekst predstavljao nepoštivanje suda. U vezi sa zabranom, Sud je utvrdio (stav 65): „Općeprihvaćena stvar je da sudovi ne mogu djelovati u vakumu. Mada oni jesu forum za rješavanje sporova, to ne znači da se o tim sporovima ne može i prije toga negdje drugo diskutirati, bilo u specijaliziranim časopisima, u općoj štampi, ili generalno u javnosti. “5

$\boldsymbol{U}$ slučaju Goodwin novinar je dobio informaciju o finansijskim problemima preduzeća. Kada se obratio preduzeću da potvrdi činjenice, ispostavilo se da je informacija izvučena iz povjerljivog izvještaja

\footnotetext{
${ }^{4}$ Opširnije vidjeti u: Harland,Christopher, Komentar Europske konvencije o ljudskim pravima: prema praksi u BiH i Strazburgu, Sarajevo, 2003. godine, str. 244.

${ }^{5}$ Opširnije vidjeti: Gilles Dutertre, Izvod iz sudske prakse Europski sud za ljudska prava, Bemust, Sarajevo, 2002. godine, str. 274-280.
} 
preduzeća. To je na kraju rezultiralo sudskom zabranom upućenoj novinaru protiv objavljivanja informacija kao i sudski nalog za otkrivanje identiteta Goodwinovog izvora. ${ }^{6}$

U predmetu Goodwin Sud je konstatovao: "Bez takve zaštite izvori bi se mogli odvratiti od pružanja pomoći štampi u informisanju javnosti o pitanjima od javnog interesa. Kao rezultat toga, vitalna uloga čuvara javnosti koju ima štampa mogla bi biti podrivena, a sposobnost štampe da daje tačne i pouzdane informacije mogla bi pretrpjeti neželjene posljedice."7

\section{U predmetu Gaskin protiv Ujedinjenog Kraljevstva (presuda} Evropskog suda od 07. jula 1989. godine, Serija A br.160.), gdje je jedan čovjek tražio pristup informacijama u vezi s njegovim porodičnim stanjem, Sud je utvrdio da je povrijeđeno pravo na privatnost iz člana 8 Konvencije, ali nije utvrdio povredu u skladu s članom 10, navodeći: „Sud smatra, kao i u navedenoj presudi u predmetu Leander, da pravo na slobodu primanja informacija u osnovi zabranjuju vlastima da sprečavaju osobu da prima informacije koje joj drugi žele prenijeti ili bi mogli željeti da prenesu (Serija A, broj 116, strana 29, stav 74). Uzimajući u obzir okolnosti vezane da pojedincu prenese pomenute informacije“. 8

Sud je pošao od toga da član 10 ne garantira bilo koje pravo pristupa sredstvima za širenje informacija, npr. pristup novinama i televiziji itd. Član 10 ne nameće bilo kakvu obavezu državama da osiguraju ikakva sredstva pojedincu kako bi mu pomogle u širenju nekih informacija.

\section{Sloboda štampe i javnog objavljivanja (sudska praksa)}

Zabrane cirkualacije, distribucije publikacije koje predstavlja prijetnju javnom redu može se ilustrirati presudom Association Ekin protiv Francuske od 10. jula 2001. godine, Predstavka br. 39288/98, stav 63, u vezi s uredbom kojom se zabranjuje, cirkulacija, distribucija i ponuda

\footnotetext{
${ }^{6}$ Opširnije vidjeti u: P.van Dijk,G. J. H.van Hoof, Teorija $i$ praksa Europske konvencija o ljudskim pravima, Sarajevo, 200. godine, str. 526.

${ }^{7}$ Ibid, str. 527.

${ }^{8}$ Opširnije vidjeti u: Harland,Christopher, Komentar Europske konvencije o ljudskim pravima: prema praksi u BiH i Strazburgu, 2003. godine, Sarajevo, str. 244.
} 
na prodaju u cijeloj Francuskoj, publikacije koja je, navodno, predstavljala prijetnju javnom redu, a koju je na kraju Državni savjet poništio. Sud se složio s Državnim savjetom da, posebno uzimajući u obzir sigurnost i javni red, sadržaj publikacije nije bio takav da može opravdati težinu miješanja u pravo podnosioca na slobodu izražavanja, predstavljenu kroz zabranu koju je naložilo Ministarstvo unutrašnjih poslova. Ukratko, Sud je smatrao da uredba Ministarstva unutrašnjih poslova nije bila odgovor na hitnu društvenu potrebu i nije bila proporcionalna legitimnom cilju koji se želio postići. ${ }^{9}$

U predmetu Observer i Guardian protiv Ujedinjenog Kraljevstva (26. novembar 1991, Serija A, br. 216, str. 29-30, stavovi 59-60), Sud je dao sažetak osnovnih principa koji se odnose na štampu i slobodu izražavanja:

a) Sloboda izražavanja predstavlja jedan od suštinskih temelja demokratskog društva; na osnovu stava 2, člana 10 (čl. 10-2), primjenjuje se ne samo na "informacije" i "ideje" koje se primaju ili se smatraju neuvredljivima ili nebitnima, već i na one koje vrijeđaju, šokiraju, ili uznemiravaju. Sloboda izražavanja, onako kako je utjelotvorena u članu 10 (čl. 10), podliježe različitim izuzecima, koji se, s druge strane, moraju tumačiti usko, a neophodnost bilo kakvog ograničenja mora se ustanoviti uvjerljivo.

b) Navedeni principi su posebno značajni kad je štampa u pitanju. Mada ne smije prekoračiti granice uspostavljene, između ostalog, $\mathrm{u}$ "interesu nacionalne sigurnosti" ili za "održavanje autoriteta pravosuđa", ipak je njena dužnost da pruža informacije i ideje o pitanjima od javnog interesa. Ne samo da štampa ima zadatak da pruža takve informacije i ideje, sama javnost ima pravo da ih prima. Da nije tako, štampa ne bi bila u stanju da igra svoju vitalnu ulogu "stražara javnosti".

c) Pridjev "neophodan", u smislu člana 10, stav 2 (čl. 10-2), implicira postojanje "hitne društvene potrebe". Države potpisnice uživaju određeni stepen slobodne procjene pri određivanju da li postoji

\footnotetext{
${ }^{9}$ Opširnije vidjeti i presudu u pogledu navedene problematike presudu Öztürk protiv Turske od 28. septembra 1999, Izvještaji 1999-VI, stavovi 64-74 : Gilles Dutertre, Izvod iz sudske prakse Europski sud za ljudska prava, Bemust, Sarajevo, 2002. godine, str. 272-291.
} 
takva društvena potreba, ali to ide ruku pod ruku s evropskim nadzorom, koji uključuje i zakone i odluke kojima se ti zakoni primjenjuju, čak i kad ih donose nezavisni sudovi. Stoga je ovaj Sud nadležan da donosi konačnu odluku o tome da li se neko "ograničenje" uklapa sa slobodom izražavanja koju štiti član 10 (čl. $10)$.

d) Pri vršenju svoje nadzorne nadležnosti, zadatak Suda nije da zauzima mjesto nadležnih domaćih vlasti, već da u svjetlu člana 10 razmatra odluke koje one donose u skladu sa svojim ovlaštenjima da slobodno procjenjuju. To ne znači da je ovaj nadzor ograničen na utvrđivanje da li je odgovorna država svoja diskreciona prava koristila razumno, pažljivo i dobronamjerno. Zadatak Suda je da razmotri miješanje koje je predmet pritužbe u odnosu na predmet $u$ cjelini i da odredi da li je ono bilo "proporcionalno cilju koji se želio ostvariti” i da li su razlozi koje su domaće vlasti ponudile kao obrazloženje bili "relevantni i dovoljni”. Naime član 10 Konvencije ne sadrži eksplicitnu zabranu nametanja prethodnih ograničenja na publikacije. Ovo se potvrđuje ne samo riječima "uslovi", "ograničenja" i "sprečavanje"; koje se pojavljuju u samoj odredbi, već i presudom Sunday Timesa koju je Sud donio 26. aprila 1979, kao i presudom Markt Intern Verlag GmbH i Klaus Beermann od 20. novembra 1989. (Serija A, br. 165). S druge strane, opasnosti koje podrazumijeva prethodno ograničenje su takve da od Suda traže najpažljiviju analizu. Ovo posebno važi kad se radi o štampi, jer vijesti su roba s ograničenim vijekom trajanja i kašnjenje $s$ objavljivanjem, makar i kratko, može ih lišti i vrijednosti i zanimljivosti. ${ }^{10}$

U predmetu Prager i Oberschlick protiv Austrije, s druge strane (26. april 1995, Serija A, br. 313), osuda novinara i izdavača za klevetu sudije nije se smatrala kršenjem člana 10. Sud je primijetio: “(...) da su navodi protiv sudije "bili izuzetno ozbiljni” (stav 36); da je "pretjeran obim optužbi (...) u odsustvu zadovoljavajućeg činjeničnog osnova, djelovao kao nepotrebno štetan" (stav 37); i da podnosilac "nije mogao

10 Presuda Association Ekin protiv Francuske od 10. jula 2001, Predstavka br. 39288/98, stavovi 56-57, ili presuda Fressoz i Roire protiv Francuske od 21. januara 1999, Izvještaji 1999-I, stav 45) Opširnije vidjeti u: Gilles Dutertre, Izvod iz sudske prakse Europski sud za ljudska prava, Bemust, Sarajevo, 2002. godine, str. 272-291. 
da se pozove na svoju dobronamjernost ili poštivanje novinarske etike. Ne može se reći da je istraživanje koje je obavio bilo dovoljno da potkrijepi tako teške navode (stav 37 )". 11

\subsection{Ograničenje slobode izražavanja - član 10, stav 2 Evropske konvencije za zaštitu ljudskih prava i osnovnih sloboda}

U članu 10, stav 2 Evropske konvencije za zaštitu ljudskih prava i temeljnih sloboda decidno se navodi: "Pošto korištenje ovih sloboda povlači za sobom dužnosti i odgovornosti, ono se može podvrgnuti formalnostima, uslovima, ograničenjima ili kaznama propisanim zakonom i neophodnim u demokratskom društvu u interesu nacionalne bezbjednosti, teritorijalnog integriteta ili javne bezbjednosti, radi sprečavanja nereda ili kriminala, zaštite zdravlja ili morala, zaštite ugleda ili prava drugih, sprečavanja otkrivanja obavještenja dobijenih u povjerenju, ili radi očuvanja autoriteta i nepristrasnosti sudstva."12

Naprimjer, u predmetu Engel $\boldsymbol{i}$ ostali zabranu da vojnici objave i distribuiraju članak u kome se kritikuju određeni viši oficiri Sud je smatrao opravdanim miješanjem u slobodu izražavanja. Međutim, Sud

11 S ozbirom na ove faktore i na "posebnu ulogu pravosuđa u društvu”, Sud je zaključio da izricanje novčane kazne i pljenidba preostalih primjeraka napadnutog lista nisu predstavljali kršenje člana 10 (stav 38). Još jedan primjer koji se odnosi na klevetu sudija - porotnika - može se naći u presudi Barfod protiv Danske od 22. februara 1989. Serija A, br. 149. Vidjeti i presudu Perna protiv Italije od 25. jula 2001. godine, Predstavka br. 48898/99, stavovi 38-48), gdje je na 291. Evropskoj konvenciji o ljudskim pravima Sud posebno kazao (stav 38): Po definiciji, mišljenje podliježe dokazivanju. Može, s druge strane, biti pretjerano, posebno ako nema nikakvog činjeničnog osnova (vidi presudu De Haes i Gijsels protiv Belgije od 24. februara 1997. godine, Izvještaji o presudama i odlukama 1997-I, stav 47).

(v) Pitanja od javog interesa o kojima štampa ima pravo da daje informacije i ideje, $u$ određenom smislu u skladu sa svojim dužnostima i odgovornošću, uključuju i pitanja vezana za funkcioniranje pravosuđa. Međutim, rad sudova, koji su garant pravde i koji igraju osnovnu ulogu u državi u kojoj postoji vladavina zakona, mora uživati povjerenje javnosti. Stoga sud treba da bude zaštićen od neosnovanih napada, posebno u svjetlu činjenice da sudije podliježu obavezi diskrecije koja ih sprečava da odgovore (vidi presudu Prager i Oberschlick protiv Austrije od 26. aprila 1995. godine, Serija A, br. 313., stav 34.)

$12 \mathrm{http}: / /$ www.humanrights.coe.int/aware/GB/publi/materials/1103 (posljednji put pregledano 18. 5. 2020. godine) 
je, također, konstatovao da se ne radi na tome da im je uskraćena sloboda izražavanja, već je samo riječ o kažnjavanju zloupotrebe te slobode s njihove strane. U predmetu Hadjianastassiou jedan oficir osuđen je zato što je objavio informacije o određenom oružju i odgovarajuće tehničko znanje s kojim se mogla nanijeti značajna šteta nacionalnoj bezbjednosti. Sud je odlučio da je osuđujuća presuda predstavljala zadiranje u slobodu izražavanja oficira što je, međutim, opravdano po stavu 2 Konvencije. Nužno je uzeti u obzir posebne uslove koji idu uz vojni život i specifične "dužnosti” i “odgovornosti” koje su obaveza pripadnika oružanih snaga. Podnosilac predstavke, oficir KETA zadužen za program rada s eksperimentalnim projektilima bio je vezan obavezom čuvanja tajnosti svega što se ticalo obavljanja njegovih dužnosti. ${ }^{13}$

Gotovo dvadeset godina nakon presude u predmetu Engel $\boldsymbol{i}$ ostali, u jednom sličnom slučaju, Sud je promijenio svoj stav i izdao sasvim drugačiju presudu. U predmetu Vereinigung Demokratischer Soldaten Osterreichs und Gubi nadležni organi zabranili su da se vojnicima distribuira privatni časopis u kome se kritikovala vojna uprava. Austrijska vlada tvrdila je da je časopis podnosioca predstavke predstavljao prijetnju sistemu odbrane zemlje i efikasnosti vojske. Sud se nije saglasio sa podneskom Vlade i izrazio je mišljenje da većina od stvari u tom časopisu: “(...) predstavlja iznošenje pritužbi, davanje prijedloga za reforme ili podsticanje čitalaca da pokrenu zakonske postupke. Međutim, uprkos često polemičkom tonu, ne čini se da su u časopisu prešli granice dozvoljenog u kontekstu pukih diskutovanja o idejama, a ono se mora tolerisati u vojsci jedne demokratske države, kao i u društvu kojem ta vojska služi." ${ }^{14}$

U svrhu postavljanja ograničenja slobode izražavanja Evropska konvencija za zaštitu ljudskih prava i temeljnih sloboda polazi od toga da se to nikako ne može raditi samovoljno i bez jasnih kriterija. Da bi se postavile granice korištenja ove slobode, mora se naglasiti da su one

\footnotetext{
13 http://www.humanrights.coe.int/aware/GB/publi/materials/1103 (posljedni put pregledano 6. 4. 2011. godine)

14 Monica Macovei, Vodič za primjenu Člana 10 Europske konvencije o ljudskim pravima (Priručnik iz oblasti ljudskih prava br.2), Savjet Europe, Strasbourg Cedex, 2008. godine, str. 37-40.
} 
sadržane u slobodama i pravima drugih, što je naravno princip ljudskih prava. U ovom slučaju da bi postojala ograničenja, moraju se ispuniti predviđeni kriteriji: da su restrikcije predviđene zakonom gdje se pod pojmom zakona podrazumijeva svaki oblik općeg pravnog akta parlamenta, profesionalnih organizacija ili međunarodnih organizacija da su u skladu s legitimnim ciljevima kako su izloženi u članu 10, vodeći računa o tome da su te mjere u skladu s postojanjem $\mathrm{i}$ funkcionisanjem jednog demokratskog pluralističkog društva. Intervencije države u ovoj oblasti može biti izvedena na više načina od kojih su najpoznatiji:

a) Zabrana primanja i širenja ideja,

b) Represija korištenja slobode izražavanja,

c) Sprečavanje kršenja ljudskih prava putem štampe koje je najčešće moguće učiniti putem klevete (diframacije) i uvrede. ${ }^{15}$

\section{Zaključak}

Sloboda izražavanja predstavlja važnu odrednicu demokratskog društva i pluralističke demokratije. Još od antičkog perioda poznato je da nema uspješnog demokratskog angažiranja čovjeka ako nije u dovoljnoj mjeri informiran o pitanjima o kojima se odlučuje. Stoga je i Montesquie inzistirao na tezi da zakone donose samo „oni koji to znaju“ tj. oni koji su dovoljno informirani o potrebama i interesima društva i društvene zajednice.

Sloboda izražavanja je klasično političko i demokratsko pravo te kao takvo zabilježeno je u Deklaraciji o pravima čovjeka i građanina iz 1789.godine: "Sloboda izražavanja misli i uvjerenja jedno je od najvrednijih prava čovjeka. Svaki građanin može slobodno da govori, piše i štampa, ali će za zloupotrebu te slobode odgovarati u slučajevima koje je zakon odredio“ (član XI Deklaracije). Isto pravo sadržano je u Univerzalnoj deklaraciji (član 19).

Nadalje pravo na slobodu izražavanja regulasano je i članom 10, Evropske konvencije za zaštitu ljudskih prava i temeljnih sloboda što je predmet analize samog rada, stoga se može zaključiti da pomenuto

${ }^{15}$ Ćazim Sadiković, Europsko pravo, Magistrat, Sarajevo, 2001. godine, str. 108. 
pravo ima niz povezanih ciljeva. Smatra se da se zaštitom slobode izražavanja razvija društvenena zajednica i dobrobit pojedinaca i da ona predstavlja preduslov funkcionalnog demokratskog sistema. Evropski sud za ljudska prava izrazio se stavom da sloboda izražavanja predstavlja jedan od suštinskih temelja demokratskog društva i jedan od osnovnih uslova njegovog napretka i samoostvarenja svakog pojedinca. Osnovni cilj člana 10 Konvencije je zaštita od proizvoljnog miješanja javnih vlasti u pravo neke osobe na slobodu izražavanja što je detaljno i prezentirano u radu kroz primjere presuda Evropskog suda za zaštitu ljudskih prava i temeljnih sloboda. U vezi s navedenim konstatuje se da nadležne vlasti mogu tražiti poduzimanje pozitivnih mjera radi zaštite prava na slobodu izražavanja. Prilikom utvrđivanja postojanja takve obaveze, mora se voditi računa o postizanju kohezije između općih interesa društvene zajednice i interesa individue.

\section{Literatura}

1. Aćimović, Mirko (2007) Filozofija mišljenja, Novi Sad, Futura publikacije.

2. Buergenthal Thomas (1998) Međunarodna ljudska prava, Magistrat, Sarajevo.

3. Dutertre Gilles (2002) Izvod iz sudske prakse Europski sud za ljudska prava, Bemust, Sarajevo.

4. ECHR (2012) Case of Vejdeland and others v. Sweeden.

5. Joecks, W., Miebach, K. (2012) Münchener Kommentar zum Strafgesetzbuch, München.

6. Macovei Monica (2008) Vodič za primjenu Člana 10 Europske konvencije o ljudskim pravima (Priručnik iz oblasti ljudskih prava br.

2), Savjet Europe, Strasbourg Cedex.

7. Sadiković Ćazim (2001) Europsko pravo, Magistrat, Sarajevo.

8. Sali Sevima i Terzić Zlatan (1996) Međunarodni dokumenti o ljudskim pravima, Pravni centar.

9. Harland Christopher (2003) Komentar Europske konvencije o ljudskim pravima:Prema praksi u BiH i Strazburgu, Sarajevo.

10. Ambos, Kai (2011) Treatise on International Criminal Law - Volume II: The Crimes and Sentencing, Oxford, Oxford University Press 


\section{Internetski izvori}

11. http://www.netnovinar.org

12. http://www.mediaonline.ba.

13. http://www.nuns.org.yu

14. http://www.netnovinar.org

15. http://www.informator.co.yu

16. http://www.poslovniforum.hr

17. http://www.idoconline.info

18. http://www.madiaonline.ba

19. http://www.cpm.edu.yu

20. https://www.media.ba 
dr. sci. Nevzet Veladžić, full professor

Univerzitet u Bihaću

Email:nevret2005@yahoo.com

dipl. iur. Anita Ramulić Mujkić

University of Bihać

Islamic Pedagogical Faculty

Email:anita_ramuli@@yahoo.com

\section{FREEDOM OF EXPRESSION-ANALYSIS OF JUDGMENTS OF THE EUROPEAN COURT OF HUMAN RIGHTS (ARTICLE 10)}

\section{Abstract}

Freedom of expression is one of the most important categories in the field of buman rights and is often the subject of controversy in legal circles, especially with regard to restrictions on freedom of expression. This right is regulated by Article 10 of the European Convention for the Protection of Human Rights and Fundamental Freedoms with a special aspect to the restriction of the same.

Therefore, the most important criterion is the fact that freedom of expression as a right is manifested until the moment when it "does not touch / threaten" the right of a third party. The paper presents the basic determinants of freedom of expression with reference to the restriction of freedom of expression and the analysis of the judgments of the European Court of Human Rights (Article 10) regarding the restriction of the same.

Keywords: freedom of expression, European Convention for the Protection of Human Rights and Freedoms, restriction of freedom of expression 
الأستاذ الدكتور نوزت ولاجيتش

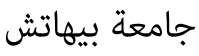

E-mail:nevzet2005@yahoo.co

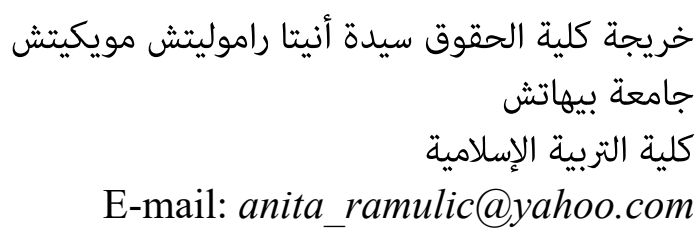

حرية التعبير - تحليل الأحكام الصادرة عن المحكمة الأوروبية لحقوق الإنسان

(1) (1)

\section{الخلاصة}

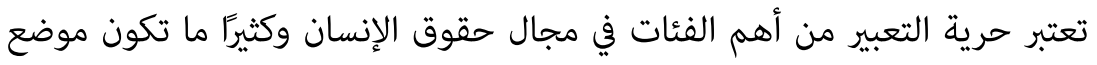

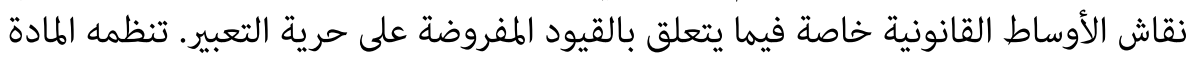

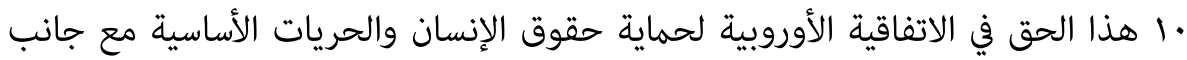

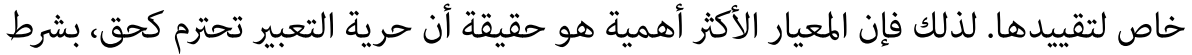

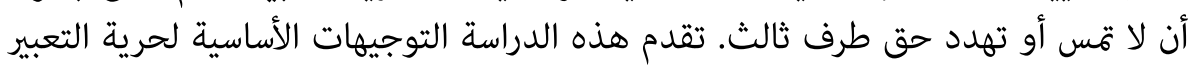

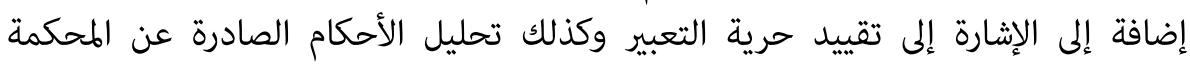

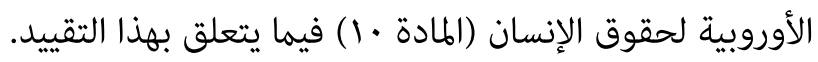

الكلمات المفتاحية: حرية التعبير، الاتفاقية الأوروبية لحماية حقوق الإنسان وحرياته، تقييد حرية التعبير. 